\title{
PSYCHE
}

VOL. XXXV.

JUNE 1928

No. 2

\section{THE BEE THAT WORKS IN STONE; PERDITA OPUNTIAE COCKERELL ${ }^{1}$}

\author{
By Clarence P. Custer, \\ University of Colorado, Boulder.
}

Some seven miles east of Boulder, nestled at the foot of the Colorado Rockies, there rise some sandstone cliffs of peculiar interest to the biologist and the geologist. These are termed the White Rocks in reference to their appearance when seen at a distance. Around them there stretch for miles and miles the fertile farming lands of Boulder County. Thus the White Rocks are isolated from other similar rock formations; and here there lives a bee that has been officially reported from nowhere else in the world. It is Perdita opuntia Ckll. ${ }^{2}$

One may find this remarkable bee in the early summer, in the months of May and June, as it hovers and darts from flower to flower in its tireless search for pollen. And in this one notices a peculiar adaptation. Apparently it visits but one plant species, the bright yellow flowers of the cactus, Opuntia mesacantha Raf., ${ }^{3}$ from which it derives its name. How specially adapted this insect is! Not content with limitation to White Rocks, it must also depend on the flowers of but one kind of plant for its existence.

${ }^{1}$ The writer is indebted to Mr. S. A. Rohwer and Miss Grace Sandhouse. for the determination of specimens; to Dr. Edna Johnson for the identification of some plants; to Miss Helen Mowry and Miss Celia Light for assistance in the photography and for helpful suggestions; to Professor R. D. George for some geological material as well as interesting information concerning tunnelways in the rock formations of different localities; and to Mrs. B. O. Custer, Miss Arline Elftman and Mr. Russel Mann for assistance in the field work.

${ }^{2}$ Determined by Miss Grace Sandhouse.

${ }^{3}$ Determined by Dr. Edna Johnson. Synonyms are O. humifusus Raf. and $O$. rafinesquii Engelm. 
Undoubtedly the question now arises as to the reason for its limitation to White Rocks. Surely this is not due to its dependence upon the cactus flowers for the same species of plant has been found quite generally distributed thruout the West. There is but one solution left. It must be dependent upon the rocks themselves. And, to be sure, I was able to show that the nest of this bee actually was in the sandstone of this locality. This seems to indicate that the bee can not make its nest in earth but only in sandstone; and being so well isolated from all other available rock formation, it of necessity is limited to White Rocks. Two facts further strengthen this explanation: First, the bee is small and a weak flier-I have not found it beyond a radius of fifty yards from the nest. Second, due to the continual tillage of the soil, the cactus plants have practically been eliminated from the adjacent territory although they are very abundant at White Rocks. Thus the bee is apparently limited to this environment.

This remarkable locality has a peculiar history. According to Professor R. D. George, head of the geology department of the University of Colorado, the White Rocks constitute the socalled "Laramie formation." This was laid down in fresh water lake basins in which, at times, vegetation grew so abundantly that extensive deposits were formed. Later, these were changed by biochemical and dynamochemical processes to coal. The sandstone over the coal was formed by the carrying of sand into the lake basin and its later solidification by pressure and an added binding material. Following this, the lake disappeared. The rock, exposed to the atmosphere, dried, shrank and the stresses were relieved by cracks radiating from centers of stress. The connections between these joints formed polygonal blocks, or "turtle backs." The joints were deepened by water freezing and thawing thereby loosening the sand grains which were later carried away by the winds. This process was repeated and in time little basins, several feet in width, were formed until now, in some cases, the joints are less emphasized. The cliffs, which rise to a height of 87 feet, were the banks of the stream which had cut out the rock along its broad valley. 
Furthermore, he made the interesting statement in August, after I had informed him that the bees were making their nests in the stone at White Rocks, that in 1903 he had seen some hymenopterous insects in some cactus flowers near Trinidad, Colorado. At the time, while working on rock formations nearby, he found some small white bodies in the stone. These he thought were the pupal cases of ants. Then it was eight years later, in 1911, that he saw the bee, Perdita opuntice, in the cactus flowers at White Rocks. At that time he saw evidence of tunnels in the stone but did not associate them with the bee. And finally, in 1924, while studying the case-hardening of the stone at Rocky Flats Lake, ${ }^{5}$ he saw similar tunnels in the rock. And so he now suggested that the bee might also be found at Trinidad and Rocky Flats Lake.

With this evidence in mind, I visited these two localities in search of the tunnels mentioned to see if by chance they could be those of P.erdita opuntioe.

Near Trinidad, 225 miles south of Boulder, the Laramie formation, of about the same hardness as that at White Rocks, was found. Cactus plants, not blooming at the time, (August) were present in some numbers but there was no evidence at all of tunnels in the stone. Only an area of ten square miles was covered. Possibly the nests might have been present nearby. But the only sure way of proving the absence of the bee from this locality would be to diligently search the cactus flowers in the month of June over an extensive area. And so, up to 1928, no bees of this species have been officially reported from the Laramie formation near Trinidad, Colorado.

In the second place, at Rocky Flats Lake, somewhat similar results were obtained. Only a very few cactus plants grew in the vicinity. However, here and there were some openings into the rock through which an iron wire could be pushed for a few inches. After chipping through the hard, granite-like surface of the stone to a depth of one or.two inches, I came upon a sandstone approximately as soft as that at White Rocks. Through this I was surprised to find that in a few instances there

${ }^{4}$ Two hundred and twenty-five miles south of Boulder.

${ }^{5}$ Twenty miles south of Boulder. 
were some tunnels about $.6 \mathrm{~cm}$. (1/4 inch) wide, to a depth of about $10 \mathrm{~cm}$. (4 inches). In them I did not find the larvæ of Perdita opuntice but a few brown cocoons of a wasp instead.

The bee which is apparently isolated at White Rocks is a small insect with black head and thorax and a clear ambercolored abdomen. It is scarcely $7 \mathrm{~mm}$. $(1 / 4 \mathrm{inch})$ long. The face of the female is black; that of the male, partly yellow. One is struck by the fact that the pollen grains on the hind legs are distinctly larger than are the ocelli or simple eyes of this insect. See Fig. 3.

Correspondingly narrow are the galleries of this bee in the sandstone. The entrances to the nests are generally found on

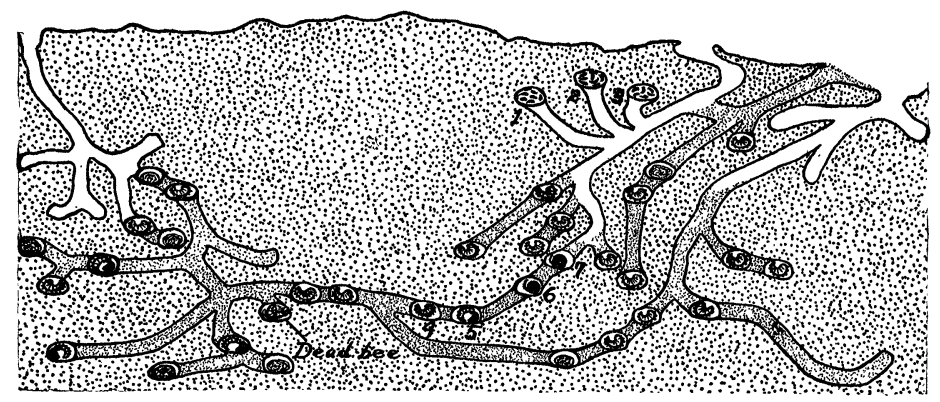

Fig 1.-The nest is composed of numerous tunnelways leading down from the surface of
the stone. The larvae with their typical double-rowed sawtooth backs are shown in some of
the cells. Heavy stippling indicates sandstone; light stippling, fine. loose sand. (Verticle
section approximately one-third natural size.)

the upper surfaces of certain dome-shaped sandstone formations, some three to five yards wide ${ }^{6}$. Each nest has several entrances. These are more or less widened by the continual erosion of the stone. Hence, in a typical nest, one would expect to find three or four openings from 1-2 to $1 \mathrm{~cm}$. in width, and separated from each other by a distance of about $10 \mathrm{~cm}$. (4 inches). Most of these entrances are open. But, in a few cases, especially those leading almost straight down, the opening is closed with fine sand. However, the bees do not have difficulty in securing their entrance to these. They can not rake the sand out to open a passageway; for the fine particles would fall back on either ${ }^{6}$ See Plate II, middle figure. 
side of their fore legs, much as would happen should we draw a needle through a cup of salt. So they merely insert their heads into the entrance, and made their way down thru the sand, which closes behind them. I have seen as many as four bees enter a nest thus in close succession, the one behind following quite close upon the disappearing abdomen of its leader. Once through the sandy entranceway, the bee attains the open tunnel, and thence proceeds without trouble. The pollen adheres to the bee's hind legs so tenaciously that but little is lost in the sand.

Since the nest has so many entrances, one would be right in assuming that there is more than one owner. Into one nest with three entrances, six bees were seen to enter. In another case I attempted to find the number of inhabitants. Armed with a stem of grass, I disturbed every bee that attempted to get out, thus causing its withdrawal into the tunnel. And, contrariwise, I permitted all bees, coming in from the fields, to enter without molestation. When I had waited thus for some fifteen minutes, and no more bees arrived, I stood back and counted the ones coming out. By this method I found thirteen bees, 11 females and 2 males.

When I was sure that all the bees had come out of the nest, I dropped some fine sand into the entrances. This filled them up, completely concealing them. Here, I took the following time notes, describing the return of the thirteen owners:

June 26. White Rocks.

$10: 47^{\prime}$. Seven bees arrive together from the fields. Unable to find the entrances, they francitally claw the sandstone, here and there, at about a centimeter from the closed openings.

$10: 50^{\prime}$. One bee finds entrance. It immediately makes way straight down thru sand. Two others see it enter, and rush to the spot, arriving a second after its abdomen has disappeared. These enter the sand in like manner.

$10: 50^{\prime}: 45^{\prime \prime}$. The last two bees come out head first, having failed to find the entrance. Pollen still on legs. They fly around a short distance from nest, alighting, at intervals, to dig wildly around entrance. 
11:01'. More bees arrive from fields. Very much excited.

$11: 03^{\prime}: 30^{\prime \prime}$.Another finds an entrance. Four others rush to the spot. These enter in succession, the one behind quite close upon the abdomen of its predecessor. Sand closes over the last bee.

11:06'. Still seven left out unable to find an entrance.

$11: 08^{\prime}: 15^{\prime \prime}$. Another bee finds an entrance. Two more follow it closely. Sand closes over last.

$11: 10^{\prime}$. Remaining bees enter nest in like manner. Entrances to nests are as well concealed as ever.

$11: 14^{\prime}: 50^{\prime \prime}$. A bee comes out, head first. Flies away.

$11: 15^{\prime}: 30^{\prime \prime}$. Returns and enters nest as before. Backs up tunnel pushing mound of sand up over the entrance with its abdomen.

$11: 18^{\prime}: 15^{\prime \prime}$. Pushes sand up again. Repeats several' times.

$11: 21^{\prime}: 30^{\prime \prime}$. Entrance now free of sand. Bee continues backing up tunnel. Several bees leave the nest by another entrance.

The bee does not come directly to the nest from the fields. It will first alight on a rock, a few meters away. Here it will remain quiet for a minute or two, and presently fly on to alight a meter or so nearer the nest. Perhaps it will pass over the nest two or three times in this manner. Finally, after having alighted several times, it will fly directly to the entrance, hover over it for a moment, and enter. This probably serves to deceive any parasites which may attempt to follow it to the nest.

This species undoubtedly builds its own nest. This is composed of numerous tunnelways leading down from the surface of the stone for a distance of about 7 to $10 \mathrm{~cm}$. (3 to 4 inches). From these several more or less horizontal galleries branch off leading to the cells for the reception of the future generations. The tunnels from several entrances often join one another at varying distances beneath the surface. Hence a nest may have several entrances. In Fig. 1, four entrances are shown. Three of these were close together and the fourth was about $20 \mathrm{~cm}$. $(8$ inches) away. The vertical depth was about $7.5 \mathrm{~cm}$. (3 inches). Most of the passageways were in about the same plane suggest- 
ing that the bees took advantage of a fault in the stone to excavate their nest. Such a crack, if present, was hardly noticeable from the surface.

In some cases, one does not find such distinct galleries branching off from the tunnels in the stone. Thus upon chiseling out the nest used by thirteen bees I came across a most peculiar structure. The tunnelways from the entrances led down in a typical manner to a depth of 2 or $3 \mathrm{~cm}$. (one inch). Here they began to branch and merged abruptly into an area of dark, moist sand about the size of one's two fists. Lower Figure Plate II is a photograph of this nest. It was taken after the moist sand with its contents had been removed. The accompanying drawing, Fig. 4, shows the larvæ as they would have appeared had the fine sand been transparent.

The explanation of such a nest is probably as follows: Apparently the bees had been working on the nest for years and years. Each season a new brood continued the work of excavation. And each year the branching galleries became more and more complicated, until, finally, nothing was left of the sandstone walls between the tunnels. Just a mass of the dark, moist sand remained.

Embedded in this chamber of sand, 215 larvæ, each within its mud-like cell, were present. Here and there was a dead adult, a silent reminder of the past season's activity. If it is true that there were but eleven females in this nest of 215 larvæ, then each female laid at least 19 eggs. ${ }^{7}$ This is in harmony with the findings of Fabre ('15). He states further that after the bee has laid her limit of eggs, she continues her work of provisioning cells which are finished and closed up just as if the egg had been laid:-

"I seem to see..... a rough image of the industrious persistency of the insect, still toiling away at its business, even when there is nothing useful left to do. This worker knows no rest but death."

Perhaps the same explanation could be offered for the presence of over a dozen such cells in this nest. In each of these

7"The total number of eggs laid not only by the Osmiæ but by a host of other bees fluctuates round about fifteen."-Fabre. 
there was found a typical ball of pollen, as had been present in all of the rest, but no signs of an egg or larva.

Some of the chambers for the young bees, i. e. numbers 1 , 2 and 3 in Fig. 1, were but a centimeter from the surface. At the time of my chiseling these out, I saw on their walls patches of pollen of the same size as the loads on the hind legs of the females. Here, the bees were apparently forming a supply of pollen before shaping it into a ball for the young embryo. The walls of these chambers were smoothly lined with a mud-like material.

Between the cells containing the larvæ the tunnel was filled up with loose sand. This was somewhat damp and more darkly colored than the surrounding stone This probably prevents certain enemies from reaching the young bees, during the hot summer months of July, August and September when the builders of the nests are dead.

In cells labeled 4, 5, 6 and 7, Fig. 1, one sees the stages in the development of the young embryo. Thus, in cell 4 there was a large, well-grown larva, without any visible pollen.

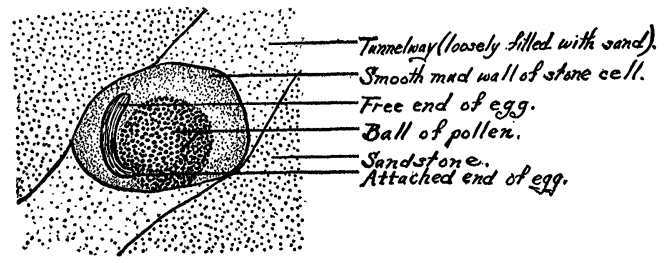

Fig 2.-The egg of the species is crescent-shaped. (Taken from Fig. 1, cell 7).

But in cell 5, the larva was not so well developed, having eaten but half of its provision of pollen and honey. The egg for this one had been laid later. Further along, in cell 6, a large ball of pollen, $2.5 \mathrm{~mm}$. in diameter was present. On its side there was a slightly developed larva, just out of the egg. And finally, in cell 7, there was a similar ball of pollen with an egg along the side. One end was inserted into the pollen. Apparently it had just been laid. This latter chamber is shown in Fig. 2. The egg of this species is somewhat crescent-shaped, quite smooth, 
glistening and opalescent. It is approximately $1.5 \mathrm{~mm}$. in length, being about one-fifth as wide as long.

In looking through the literature, I find no report of any bee, or wasp, for that matter, digging its nest out of stone. In the study of the thousands of species of wild bees one finds many different methods of nesting. The most common of all bees, those of the genus Megachile, excavate tunnels, to a depth of several inches, in the earth or in other suitable places such as the dried stems of pithy plants. In these they construct several cells, each about a centimeter long, out of pieces of leaves which they cut from nearby plants. These cells are partially filled with pollen and honey and an egg is laid therein. This hatches and usually takes a year to mature. The process is then repeated. Each nest is usually built by but one bee; she lives but a month or two. The males never help in the nesting. Bees of another genus, Xylocopa, excavate similar tunnels in wood and use sawdust to make the cells. Others, of the genus Anthidium, find tunnels already constructed, usually in the earth. In these, they place cells made of a cottony material consisting of hairs scraped from plant stems. Then they fill up the tunnel above the cells with the cottony material, soil or pebbles, etc., according to the species. And others of the genus Dianthidium construct their cells out of a resin which they secure from certain plants, such as the sunflower, Helianthus petiolaris. Here it occurs in drops on the leaves and stems. Some of the species make their cells on rocks, others in the ground etc. Some are solitary; others are colonial. One of the latter species even keeps two nests going at the same time. See Custer and Hicks ('27). Still others, known as the burrowing bees, such as those of the genus Melissodes or Anthophora, dig out extensive galleries in the earth. These line their cells with a smooth mud-like material probably made by lapping the cell-walls with their tongues. Then there are the bees of the genus Osmia that dig tunnels in the earth, old logs etc. These construct their cells out of macerated plant leaves etc. And, finally, there are bees that make no nests at all. They are parasites on other bees. Among these we find the genera Colioxys (parasitic on Mega- 
chile), Triepeolus (on Melissodes etc.), and others. They lay their egg alongside that of the host in the cell. Then, according to Fabre ('15), the parasite's egg hatches out and its first instinct is to seek out and destroy the egg of the host. It then develops, usually throughout the winter to come out the next summer as the adult. Thus each bee and each genus has its own peculiar methods of nesting. Many more interesting details can be obtained from Fabre's works. And many interesting facts remain yet to be found in nature.

The small bees of the genus Perdita are found chiefly in the arid south-western region of the North American Continent. Some have been found in Canada ( $P$. canadensis Crawford and

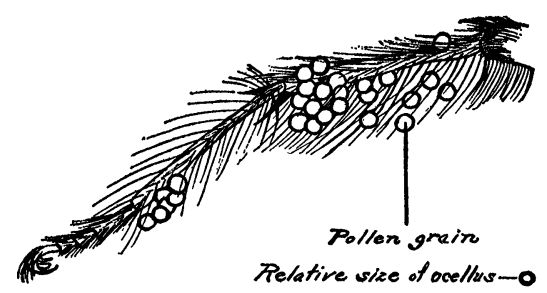

Fig 3.-The pollen grains on the hind legs of the female are larger than the ocelli. (Hind leg of female X33 diameters).

$P$. citrinella Grænicher); others in Mexico ( $P$. mexicanorum Ckll). ${ }^{8}$ Between these two countries the bees of this genus are abundant, especially in New Mexico. P. albipennis, a western form, is found from South Dakota and Nebraska through Colorado and New Mexico into Texas, according to Grænicher ('14).

Before Professor Cockerell ('96) started his work on this genus, only 17 species were known. By 1896 he had added 53 new species to the list. Of these, 26 were known in both sexes, 26 only in the male, 18 only in the female. The flower visiting habits of 50 species were known. Their nesting habits were as yet unknown. Fifteen years later, in 1911, he reported a list of

8Prosessor Timberlake informs me that the genus is recorded on the Atlantic coast from Guatemalo to New Brunswick; on the Pacific coast from Lower California to Victoria, British Columbia, at which latter place he has found an as yet undescribed species. He is at present describing some fifty new species, mostly from California. 
149 members, over twice as many as were known in 1896. By 1922 the list had been further enlarged by at least ten more species. Up to this time, the nests of but two species had been observed: In 1910 Grænicher had reported that $P$. maculipennis made its nest in sandy soil in Wisconsin. And in $1920 \mathrm{~J}$. Bequaert ('20) had stated that $P$. octomaculata was seen nesting in sandy soil at Forest Hills.

By 1896 only two species were found east of the Mississippi These were $P$. octomaculata Say, a northern type, and P. obscurata Cr., a southern species occurring in Georgia and Florida. However, by 1914, twelve eastern species were reported. Six of these were from Wisconsin.

According to Professor Cockerell and others, it may be laid down as a general rule that each species of Perdita visits, normally, but one species of flower. More than half of these flowers are Composito. These bees do not usually frequent the northern type of flowers but rather those that extend northward from the neotropical region. This, taken with the normal distribution of the genus, strongly suggests that in the main we have to do with a southern series of types which have spread northward and become largely differentiated since the glacial epoch. But we must look upon $P$. octomaculata as a survivor from pre-glacial times.

The great majority of the members of this genus fly in the late summer and autumn. Few have been seen both in spring and late summer but Viereck (Ckll'11) has collected $P$. phacelice in May and $P$. pectidis in April in New Mexico, these being previously known as September bees. And so in these cases there are apparently two broods each year or else the September brood hibernates through the winter. At White Rocks, but one brood of $P$. opuntice is found each year. Even by December I have been unable to find any cocoons spun by the larvæ. The cocoons shown in Fig. 1 are probably those of parasites.

Perdita opuntice is not the only bee that confines its visits to the cactus flowers. Professor Cockerell has shown that the genus Lithurgus and certain members of Heriades and Ashmeadiella are confined to their flowers for their pollen. Professor 
Toumey has shown that certain species of cactus have almost lost the ability to produce seed but propagate by means of falling joints which take root, and yet their flowers are adapted to bees and are visited by a series of bees more or less peculiar to them. Thus Ashmeadiella cactorum Ckll. visits cactus at Santa Fé in July.

These bees are usually short of flight. Some claim that this is so because they are small. Others want proof for such statements and offer other explanations. Thus Robertson ('12) explains it by saying that the short flight is the result of the visiting of the few closely allied genera of plants. In order to visit a few genera they have to be where those few are abundant. And so each year they nest in the neighborhood of the flowers on which they depend. Being near to these flowers each season, they are therefore short flighted. Both opinions are probably right. Apparently but little actual field work has been done on this problem.

It is evident that there are other bees of this genus which are apparently limited by their environment as much as is Perdita opuntice. Thus M. H. Swenk and T.D.A. Cockerell ('07)

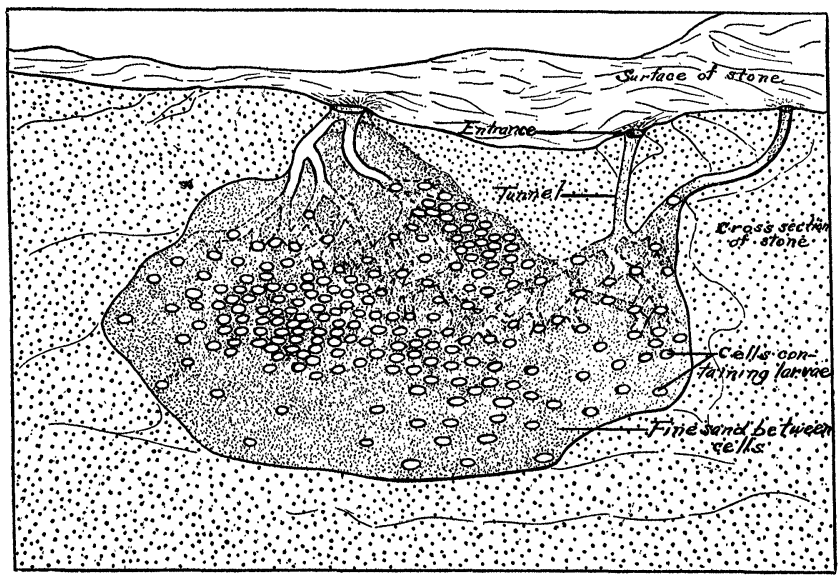

Fig 4.- A drawing explaining Plate II, lower figure. This is a vertical section through the sandstone. The cells are shown as rhough the sand between them were transparent. In
reality they are in several different planes. 
state that $P$. crawfordi Ckll. has never been taken away from the environs of the salt flats west of Lincoln, Nebraska. Perhaps in this as well as in other cases, similar geological limits are set on the bee, the same as on $P$. opuntio. Further investigation of this point would probably be interesting.

Various investigators have found evidences of adaptation to new conditions, of extraordinary splitting up into a great variety of forms and, in general, of considerable signs of evolution going on within this genus. Professor Cockerell thus states "we have indeed the process of evolution going on under our eyes, the puzzling forms being those which have only lately segregated themselves and have not yet developed striking peculiarities." Grænicher brings forth some evidence when he states that $P$. maculipennis obtains her pollen from the white melilot which was introduced from Europe. Here there occurred an adaptation to new conditions brought about by the fact that the native plant or plants visited originally by this bee did not occur in the type locality at the time the bee was found.

With these facts in mind, Professor Cockerell has advanced the following five possibilities of processes that may be going on in the formation of new species in the genus Perdita:

1. Mutations having no adaptive significance.

2. Results of the crossing of mutants.

3. The sorting out of certain characters as dominant (in the sense of prevalent) but not necessarily aided by natural selection or sexual selection.

4. The occasional coincidence of adaptive features (often physiological or such morphological ones as length of tongue) which favor a change of habits or environment and permit the insect to become attached to a different genus of plants.

5. The new type having been isolated on a new plant, or geographically or seasonally isolated will eventually settle down to a new position of stability (aided by natural selection) which will be sufficiently remote from that of the parent species to maintain it as a distinct entity in nature, and usually prevent crossing. 
The complexity of the genitalia will cause slight modifications to result in physiological isolation.

In the case of the bee, Perdita opuntice, progressive excavation of the nest is probably continued year after year, by this means leading to the complicated galleries in the stone. In Fig. 1 , the nest at the extreme right had four blind pockets which were not constructed into chambers. In other places, similar extensions were present. These, along with the old chambers, undoubtedly would have been used by the next year's brood.

In places, as labelled in this same drawing, one could see a cocoon $^{9}$ or dead bee. So, by June 21, when the nest was chiseled out, the process of provisioning was near completion. By the first of July, the cactus flowers were beginning to disappear, and by the eighth not. a bee of this species was to be seen at White Rocks. Just a very few of the cactus flowers remained. The bee had disappeared for the year. The larvæ were beginning their long period of development, waiting quietly through the long months of the hot summer and bleak winter in their cells of stone, inpreparation for the emergence next spring as adult bees.

Before this time, on June 20, I had covered the White Rocks from end to end mapping out the distribution of the bees as I found them in the cactus flowers. This covered a territory two and a half miles long by one quarter mile wide. Everywhere that I found the cactus flowers, numbers of these bees were present. This plant is a native of this country. Beyond a doubt, when the Indians used the White Rocks as a look-out station, ${ }^{10}$ in the pre-pioneer days, the cactus plants were quite generally distributed all around the territory. Perhaps a long time before that there were numerous rock formations all over the West, in which the bee made its nests. As time passed on, these disappeared, leaving the White Rocks as an erosive remnant on which Perdita opuntice and its favorite cactus flowers were stranded. Perhaps extensive collecting would reveal this bee at some other sandstone formation where it had been similarly isolated. Up to this time, September, 1927, no such proof is

${ }^{9}$ Probably of a parasite.

${ }^{10}$ Numerous implements used by the Indians have been recovered from the White Rocks. These include, especially, mortars, pestles, etc. 


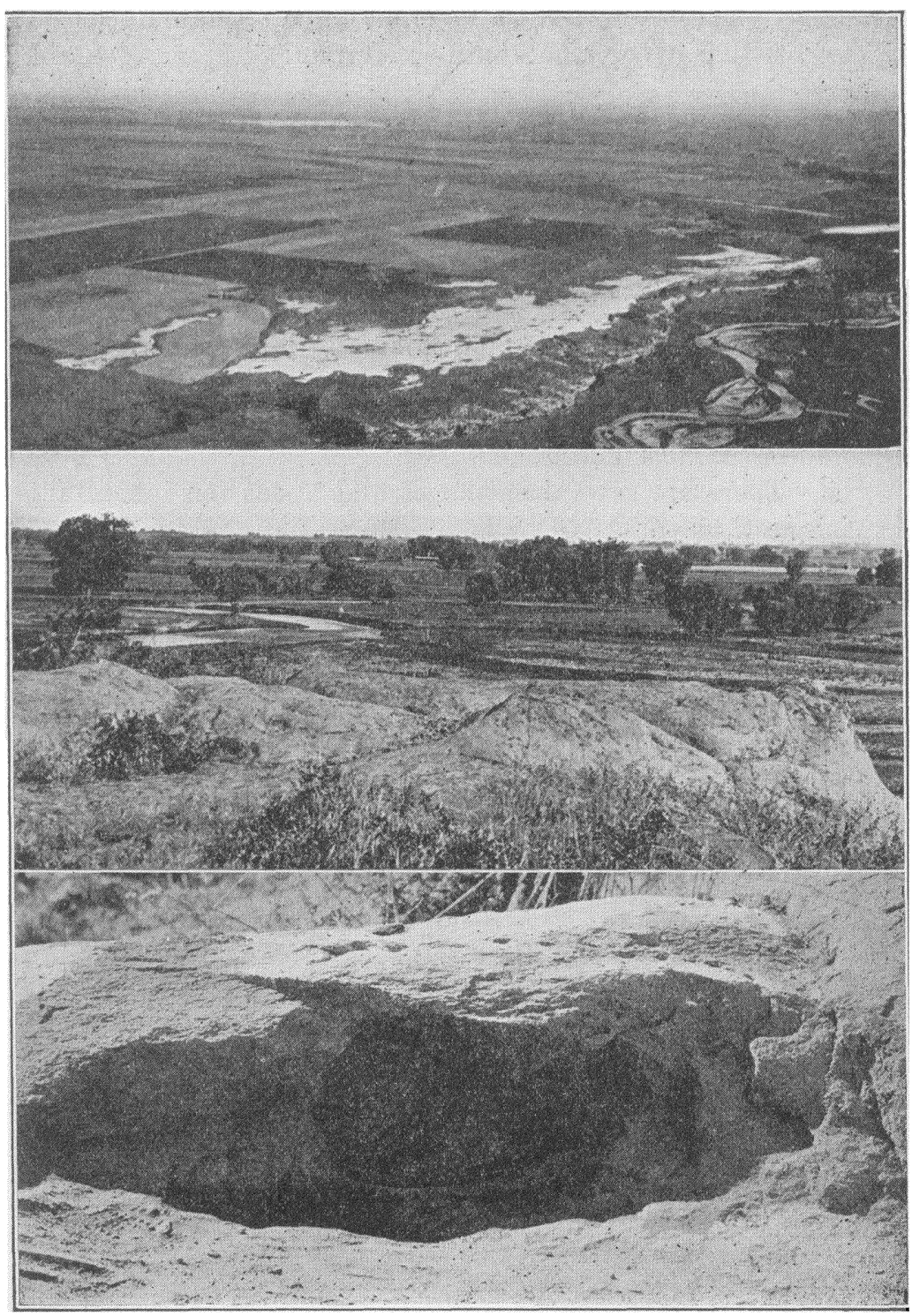

CUSTER-PERDITA 
available. The bee is still to be found only at White Rocks. Is it possible that it arose here in its evolution?

\section{SUMMARY.}

1. Perdita opuntice is a wild bee which has been reported from nowhere else but White Rocks, Colorado.

2. It is isolated here because it must make its nest in sandstone.

3. The isolation of White Rocks by large areas of tilled land prevents the spread of this bee.

4. It visits the flowers of but one plant species, the cactus, Opuntia mesacantha Rafinesque.

5. There are several entrances and about ten inhabitants to each nest.

6. The bees usually alight several times on nearby rocks before entering their nests.

7. In some cases, the inhabitants have the peculiar habit of disappearing into the sand to gain entrance to their nests.

8. Perdita opuntice is to be found at White Rocks during the latter part of May, all of June and early July.

9. This is apparently the first bee reported to make its nest in stone.

\section{BIBLIOGRAPHY}

1. Bequart, $J$.

'20 Hymenoptera Collected near Boston, Mass., with Description of a Variety of Bombus affinis. Psyche, 27: 6-12.

2. Cockerell, T. D. A.

'96 The Bees of the Genus Perdita F. Smith. Proc. Acad. Nat. Sci. Philadelphia, 48: 25-107. 15 figs.

3. Cockerell, T. D. A.

'00 The Cactus Bees; Genus Lithurgus. The Amer. Naturalist, 34: 487-488.

4. Cockerell, T. D. A.

'11 A List of the Bees of the Genus Perdita Smith. Psyche, 18: 134-143. 
5. Cockerell, T. D. A.

'19 The Bees of Peaceful Valley. Jour. New York Entomological Society, 27: 298-300.

6. Cockerell, T. D. A.

'22 Bees of the Genus Perdita from the Western States.

American Museum Novitates, 33:115.

7. Custer C. P. and Hicks C. H.

'27 Nesting Habits of Some Anthidiine Bees. Biol. Bull. 52: 258-277.

8. Custer, C. P.

'27 Nest Habits of a Solitary Bee of the Genus Spinoliella of Ashmead. Psyhe 34: No. 6, 200-202.

9. Fabre, J. Henri.

'15 Bramble Bees and Others. English Trans. New York.

10. Grwnicher, S.

'10 Wisconsin Bees; New and Little Known Species. The

Canad. Ent., April: 101-104.

11. Gronicher, S.

'14 Wisconsin Bees of the Genus Perdita. The Canad. Ent., 46: 51-57.

12. Molyshev, S. I.

'27 The Nesting Habits of Dasypoda Latr. (Hym., Apoidea);

Travaux de la Société des Natulatistes de Leningrad (Petrograd); r., T. lvi B. 2.; pp. 123-146.

13. Robertson, Charles.

'12 Origin of Oligotropy of Bees (Hym.). Ent. News, 25: 67-73.

14. Swenk M. H. and Cockerell, T. D. A.

'07 The Bees of Nebraska, Family Panurgince. Genus Perdita Smith. Ent. News, Feb.: 51-58. 


\section{Explanation of Plate II.}

Above

The home of the Worker in Stone. This is a view from an aeroplane looking north-east. It shows the complete isolation of White Rocks. In the right corner runs the stream in double "S" formation. The white streak at the extreme right is the tail of the aeroplane.

\section{Middle}

The entrances to the nests are generally found on the upper surfaces of certain dome-shaped sandstone formations. In the background runs the stream which has carved the cliffs of White Rocks. Ten or twelve nests are present in this picture.

\section{Below}

A peculiar nest that was over-tunneled by the bees. This photograph was taken, after the sand containing the cells had been scraped away, in order to give depth to the drawing in Fig. 4. (Approximately one-fourth natural size.) 

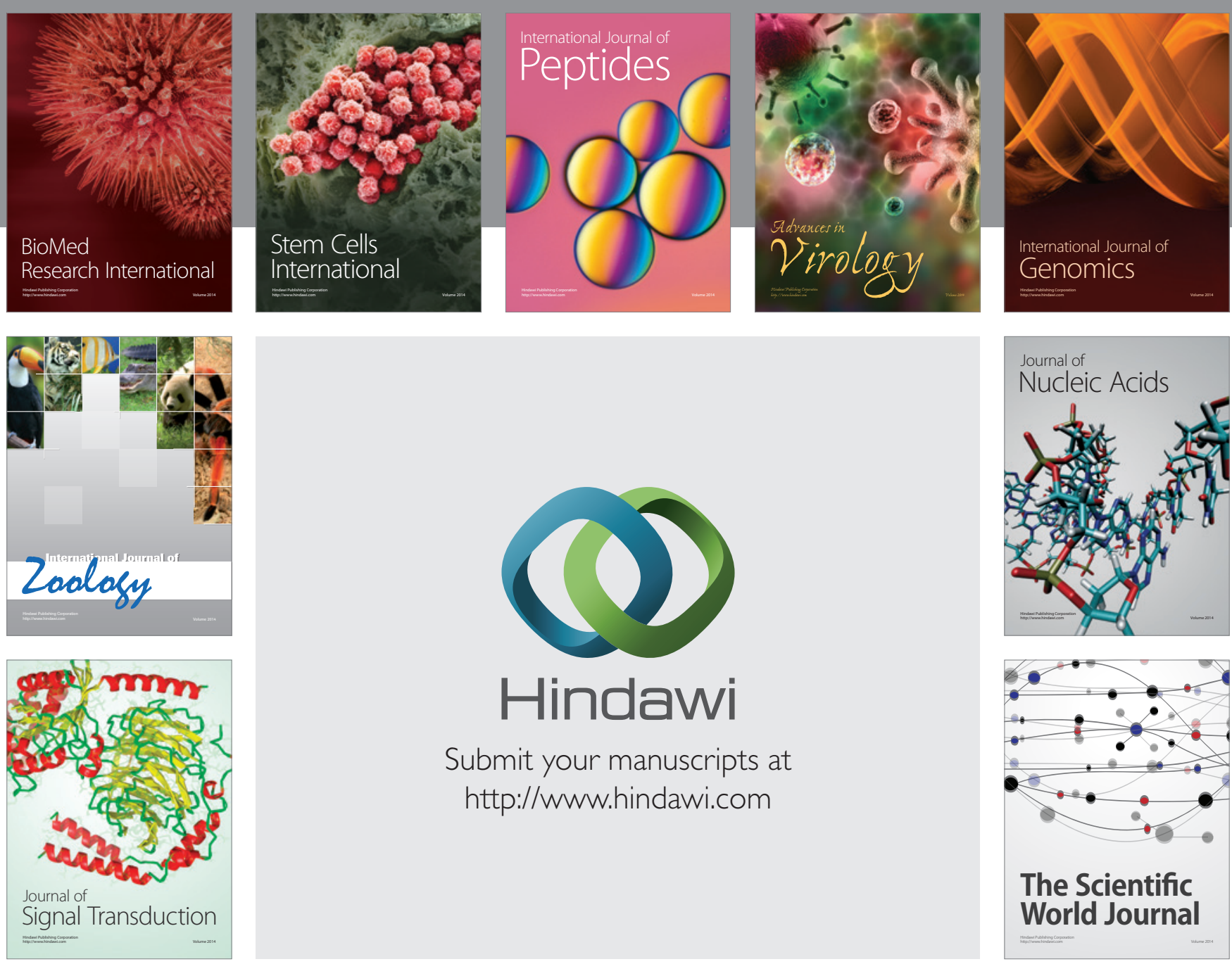

Submit your manuscripts at

http://www.hindawi.com
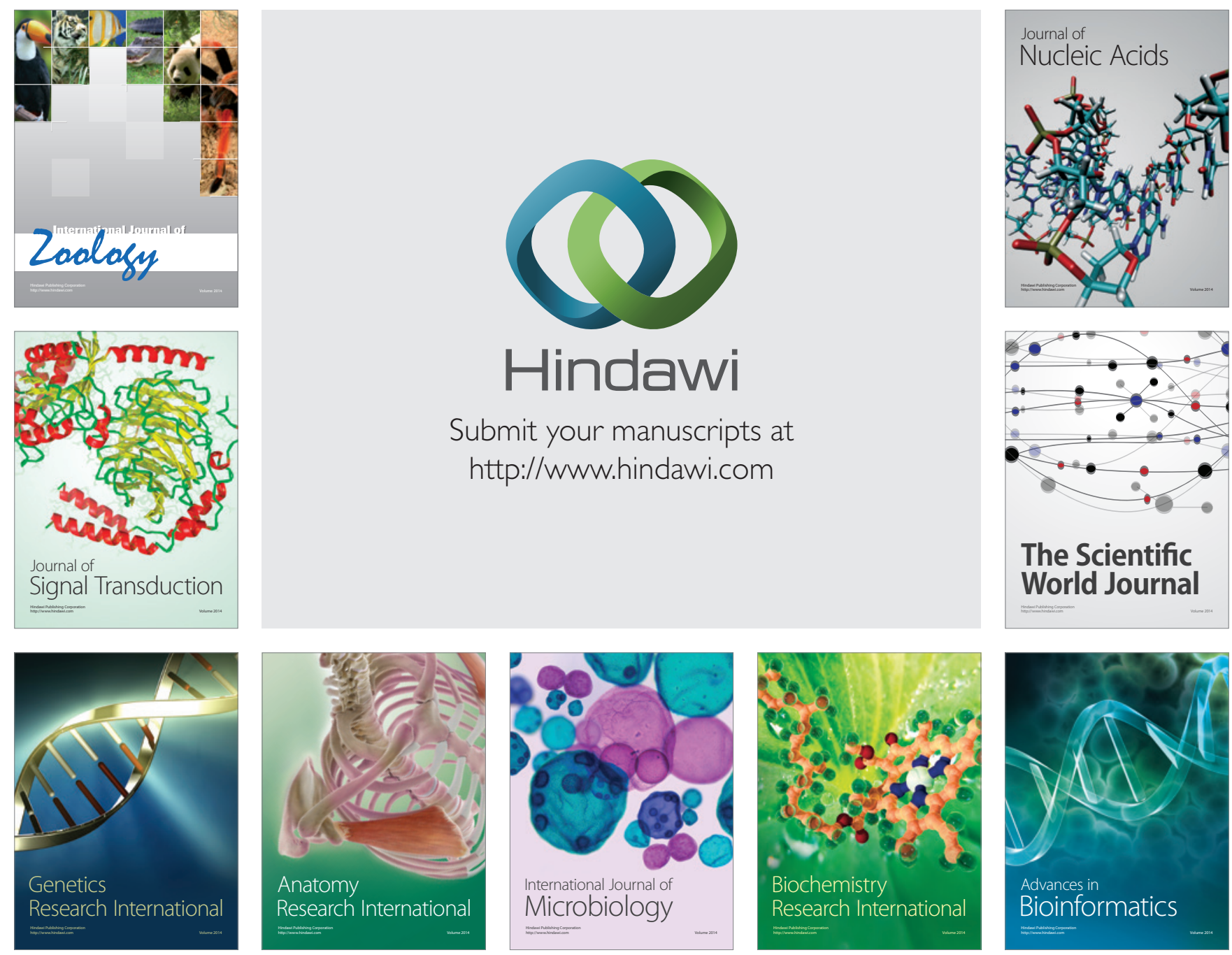

The Scientific World Journal
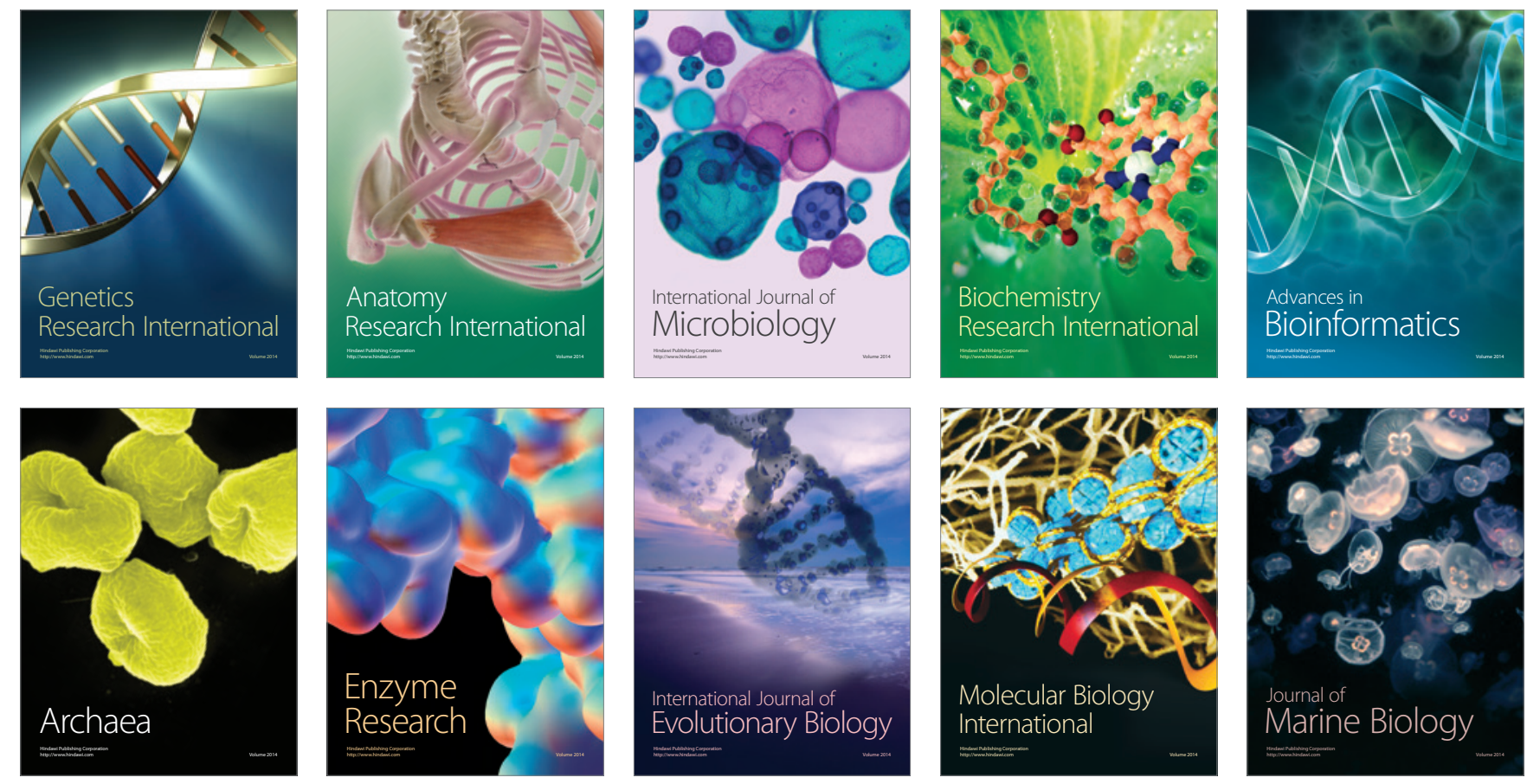